\title{
Peranan Perkongsian Pengetahuan Terhadap Jangkaan Tempoh Graduasi Mahasiswa Pasca ljazah
}

\author{
Nur Rifhan A. Rahima ${ }^{*}$, Ahmad Jusoha, Hamdan Said ${ }^{b}$ \\ ${ }^{a}$ Fakulti Pengurusan, Universiti Teknologi Malaysia, 81310 UTM Johor Bahru, Johor, Malaysia \\ ${ }^{b}$ Fakulti Pendidikan, Universiti Teknologi Malaysia, 81310 UTM Johor Bahru, Johor, Malaysia
}

*Corresponding author: riefhan206@yahoo.com

Article history

Received :26 March 2013

Received in revised form

20 August 2013

Accepted :25 August 2013

\begin{abstract}
The purpose of this study is to identify the critical success factors that influences the expected graduation time for postgraduate student. It also explores the interaction of knowledge sharing activities and the expected period of postgraduate students graduated. This research involves of 210 respondents from postgraduate research students in the field of Social Sciences at UTM, Johor Bahru. Faculty of Management and Human Resource Development (FPPSM) and Faculty of Education (FP) are involved in the study through a quantitative survey approach. Respondents answered the questionnaire given by the "Google Docstoc" application. Data analyzed using Statistical Package for Social Sciences (SPSS) Version 18.0. The critical success factors are made up of an individual's factor, quality of supervision and organizational support factors. The result showed that individual factors, quality of supervision factors and organizational support factors have a positive relationship with the expected period of graduation in a significant level of $\mathrm{p}<0.05$. Results also showed that the activity of knowledge sharing activities is the moderator for quality of supervision factors and organizational support factors at a significant level of $\mathrm{p}<0.05$.
\end{abstract}

Keywords: Individual factors; quality of supervision factors; organizational support factors; knowledge sharing activities

\begin{abstract}
Abstrak
Kajian ini adalah bertujuan untuk mengenal pasti faktor-faktor penentu kejayaan yang mempengaruhi jangkaan tempoh tamat pengajian mahasiswa pasca ijazah. Kajian ini juga ingin melihat interaksi aktiviti perkongsian pengetahuan dengan jangkaan tempoh tamat pengajian mahasiswa pasca ijazah. Kajian ini telah melibatkan seramai 210 orang responden daripada mahasiswa pasca ijazah penyelidikan dalam bidang Sains Sosial di UTM, Johor Bahru. Fakulti yang terlibat adalah Fakulti Pengurusan dan Pembangunan Sumber Manusia (FPPSM) dan Fakulti Pendidikan (FP). Borang kaji selidik merupakan instrumen utama bagi menjawab setiap soalan yang diutarakan. Aplikasi "Google Docstoc" telah diaplikasikan dalam mengagihkan borang soal selidik kepada responden. Kesemua data dianalisis dengan menggunakan perisian Statistical Package for Social Sciences 18.0 (SPSS). Faktor-faktor penentu kejayaan yang diketengahkan adalah terdiri daripada faktor individu, faktor kualiti seliaan dan faktor sokongan organisasi. Hasil kajian menunjukkan bahawa faktor individu, faktor kualiti seliaan dan faktor sokongan organisasi mempunyai hubungan positif dengan jangkaan tempoh tamat pengajian pada tahap signifikan $\mathrm{p}<0.05$. Hasil kajian juga menunjukkan bahawa aktiviti perkongsian pengetahuan merupakan moderator bagi faktor kualiti seliaan
\end{abstract} dan faktor sokongan organisasi pada tahap signifikan $\mathrm{p}<0.05$.

Kata kunci: Faktor individu; faktor kualiti seliaan; faktor sokongan organisasi; aktiviti perkongsian pengetahuan

\subsection{PENGENALAN}

Program pasca ijazah diwujudkan bagi memberi peluang kepada mahasiswa lepasan Ijazah Sarjana Muda untuk meneruskan pengajian di peringkat yang lebih tinggi iaitu di peringkat Sarjana dan Doktor Falsafah.Menerusi program ini, mahasiswa dapat meneruskan hasrat dan impian untuk meningkatkan pencapaian dalam bidang akademik di peringkat yang paling tinggi. Proses bagi menamatkan pengajian di peringkat pasca ijazah adalah sangat panjang dan sangat sukar seperti yang telah dibuktikan di mana hanya sebahagian daripada keseluruhan mahasiswa pasca ijazah yang dapat menamatkan pengajian (Leatherman, 2000). Senario bagi mahasiswa pasca ijazah yang gagal menamatkan pengajian atau mengambil tempoh masa yang panjang dalam menamatkan 
pengajian bukan sahaja dibincangkan di peringkat tempatan tetapi juga turut mendapat perhatian di peringkat antarabangsa (Leatherman, 2000).

Perkongsian pengetahuan tergolong dalam pengurusan pengetahuan.Perkongsian pengetahuan didefinisikan sebagai pertukaran pengalaman, maklumat, atau pemahaman ke atas sesuatu perkara dengan andaian ingin menambahkan maklumat dan memahami sesuatu perkara (Gouldner, 1960). Definisi ini membayangkan satu situasi di mana seseorang individu itu mempunyai perasaan ingin tahu akan sesuatu perkara (Gouldner, 1960). Perkongsian pengetahuan ini berlaku apabila individu itu bersedia untuk saling membantu antara satu sama lain serta mahu belajar daripada orang lain dengan tujuan untuk menjadi lebih cekap (Goh, 2002). Institusi pengajian tinggi pada masa ini dilihat tidak lagi hanya menawarkan pengetahuan kepada para mahasiswa, tetapi juga mengurus dan menggabungkan pengetahuan yang dimiliki melalui perkongsian pengetahuan dalam kalangan mahasiswa (Sizer, 2001). Oleh itu, perkongsian pengetahuan dalam kalangan mahasiswa akan memberi cabaran dan menjadi konsep penting kepada IPT.

Aktiviti perkongsian pengetahuan di dalam organisasi bukan berteraskan pendidikan ini dilihat sebagai isu penting kerana pengetahuan dianggap sebagai sumber penting dalam persaingan antara organisasi dan merupakan modal yang strategik dalam ekonomi maklumat. Ini bermaksud, pengetahuan yang berkembang dalam sesebuah organisasi akan meningkatkan keupayaan persaingan antara organisasi (Yang \& Wu, 2006). Ini kerana, aktiviti perkongsian pengetahuan ini telah mewujudkan satu budaya perkongsian antara pekerja dan majikan khususnya dalam perkongsian kepakaran dan idea yang bernas dan berguna kepada organisasi. Oleh itu, adakah aktiviti perkongsian pengetahuan juga perlu diwujudkan dan diaplikasikan dalam pengajian mahasiswa pasca ijazah penyelidikan Sains Sosial UTM bagi membolehkan mahasiswa pasca ijazah menamatkan pengajian dengan lebih cepat?.

Kajian terdahulu seperti Seagram (1998), Price (2005), Sheridan dan Pyke (1994), Jiranek (2010), Norhasni dan West (2007) dan Norhasni (2006) hanya melihat faktor individu, faktor kualiti seliaan dan faktor sokongan organisasi berhubungan secara langsung dengan tempoh masa mahasiswa pasca ijazah menamatkan pengajian. Namun, kajian mereka tidak memberi perhatian kepada aspek perkongsian pengetahuan dalam mempengaruhi tempoh masa mahasiswa pasca ijazah untuk menamatkan pengajian. Bagi Manathunga (2002), tingkah laku mahasiswa seperti sikap suka mengubah topik kajian, sikap mengelak daripada bertemu penyelia, sikap suka mengasingkan diri daripada orang lain dan sikap mengelak daripada menghantar kerja-kerja penyelidikan untuk semakan merupakan faktor individu yang memberi kesan dalam menamatkan pengajian. Bagi Magnuson et al., (2000) tingkah laku penyeliaan dari sudut pentadbiran, kognitif dan afektif merupakan faktor kualiti seliaan yang mempengaruhi mahasiswa menamatkan pengajian. Faktor sokongan organisasi seperti pentadbiran universiti memberi kesan kepada tempoh mahasiswa pasca ijazah menamatkan pengajian (Smith, 2002; Cude, 2001).

Aktiviti perkongsian pengetahuan di institusi pendidikan juga dilihat sangat wajar untuk dilaksanakan kerana institusi pendidikan kini memainkan peranan sebagai tempat pengumpulan pengetahuan dan tidak lagi hanya sebagai penyampai pengetahuan kepada mahasiswa (Mohd Sadiq \& Salina, 2009). Mitchell (2005) menyatakan bahawa aktiviti perkongsian pengetahuan di kalangan mahasiswa dan institusi pendidikan bukan hanya untuk menyimpan maklumat, tetapi juga untuk mengembangkan pengetahuan melalui proses pertukaran dan perkongsian pengetahuan dalam organisasi ke arah pembangunan dan pertumbuhan organisasi pada masa hadapan. Aktiviti perkongsian pengetahuan dalam kajian ini merujuk kepada sesi kolokium, seminar, internet seperti e-mel, blog, perjumpaan dalam kumpulan $\mathrm{PhD}$, dan perbincangan secara bersemuka bersama rakan-rakan mahasiswa, rakan-rakan luar universiti, professor, tutor dan penyelia.

Objektif utama kajian ini adalah:

i) Melihat perbezaan jangkaan tempoh tamat pengajian berdasarkan faktor demografi bagi mahasiswa pasca ijazah Sains Sosial di UTM.

ii) Mengenal pasti hubungan antara faktor individu, faktor kualiti seliaan dan faktor sokongan organisasi dengan jangkaan tempoh tamat pengajian di kalangan mahasiswa pasca ijazah Sains Sosial di UTM.

iii) Mengenal pasti aktiviti perkongsian pengetahuan sebagai moderator bagi perhubungan antara faktor individu, faktor kualiti seliaan dan faktor sokongan organisasi dengan jangkaan tempoh tamat pengajian.

\subsection{SOROTAN KARYA LEPAS}

Sorotan karya lepas adalah berhubung dengan faktor-faktor penentu kejayaan bagi mahasiswa pasca ijazah menamatkan pengajian mereka di peringkat Sarjana atau Doktor Falsafah. Selain itu,sorotan karya lepas juga berhubung dengan aktiviti perkongsian pengetahuan yang dijadikan sebagai moderator bagi perhubungan faktor-faktor penentu kejayaan dalam mempercepatkan atau memendekkan proses atau tempoh masa bagi mahasiswa pasca ijazah untuk menamatkan pengajian.

\subsection{Faktor-faktor Penentu Kejayaan yang Mempengaruhi Tempoh Pengajian Mahasiswa}

Bagi Jiranek (2010), jantina mahasiswa pasca ijazah di Fakulti Sains adalah signifikan dengan tempoh menamatkan pengajian di mana mahasiswa lelaki mengambil purata masa lebih awal untuk menamatkan pengajian berbanding mahasiswa wanita kerana mahasiswa wanita mengambil cuti rehat yang banyak berbanding mahasiswa lelaki. Tuckman et al., (1990) dan Yeates (1991) menyatakan bahawa mahasiswa lelaki dijangka lebih awal menamatkan pengajian kerana mahasiswa lelaki lebih peka terhadap aktiviti persekitaran yang berlaku sepanjang penyelidikan dilakukan dan mahasiswa lelaki dilihat lebih berinteraksi dengan penyelia berbanding mahasiswa wanita. Kajian daripada Aina et al., (2009) menyatakan bahawa mahasiswa wanita lambat menamatkan pengajian kerana mereka ingin menamatkan pengajian dengan gred yang lebih tinggi.Manakala, Seagram (1998) dan Sheridan dan Pyke (1994) mendapati faktor jantina tidak mempengaruhi tempoh masa mahasiswa menamatkan pengajian. Memandangkan dapatan kajian lepas banyak memperlihatkan perbezaan tamat tempoh pengajian mengikut faktor jantina, maka hipotesis 1 bagi kajian ini adalah:

\section{Hipotesis 1: Terdapat perbezaan tempoh menamatkan pengajian dalam kalangan mahasiswa pasca ijazah mengikut jantina.}

Price (2005) mengkaji status perkahwinan mahasiswa pasca ijazah boleh menjejaskan kemungkinan tempoh masa mahasiswa menamatkan pengajian.Kajian membuktikan mahasiswa yang sudah berkahwin lebih awal menamatkan pengajian berbanding mahasiswa yang mahasiswa bujang. Jiranek (2010) pula menyatakan mahasiswa yang sudah berkahwin lambat menamatkan pengajian terutama di kalangan mahasiswa wanita kerana mahasiswa wanita banyak mengambil cuti rehat termasuklah cuti bersalin. Namun, Sheridan dan Pyke (1994) 
menunjukkan status perkahwinan sebagai tidak signifikan dan tidak mempengaruhi tempoh masa mahasiswa menamatkan pengajian. Memandangkan terdapat perbezaan dapatan dalam kajian lalu dan sememangnya terdapat perbezaan komitmen bagi golongan bujang dan berkahwin, maka, hipotesis 2 bagi kajian ini adalah:

Hipotesis 2: Terdapat perbezaan tempoh menamatkan pengajian dalam kalangan mahasiswa pasca ijazah mengikut status perkahwinan.

Status pendaftaran mahasiswa adalah signifikan dengan tempoh masa mahasiswa menamatkan pengajian. Menurut Seagram (1998), mahasiswa yang telah mendaftar pengajian secara sepenuh masa dan bertukar status kepada separuh masa mengambil masa lebih lama untuk menamatkan pengajian berbanding mahasiswa yang kekal mendaftar pengajian secara sepenuh masa. Sheridan dan Pyke (1994) pula menunjukkan mahasiswa pasca ijazah yang mendaftar pengajian secara sepenuh masa mengambil tempoh masa yang lebih pendek untuk menamatkan pengajian berbanding mahasiswa yang mendaftar pengajian secara separuh masa. Ini disebabkan oleh kesukaran yang dihadapi oleh mahasiswa dalam membahagikan komitmen antara tugas sebagai mahasiswa dan pekerja. Hipotesis 3 kajian ini adalah:

Hipotesis 3: Terdapat perbezaan tempoh menamatkan pengajian bagi mahasiswa pasca ijazah berdasarkan mod pengajian.

Bagi status kewarganegaraan, Sheridan dan Pyke (1994) memberikan hasil yang berbeza antara mahasiswa Sarjana dan mahasiswa Doktor Falsafah.Mahasiswa antarabangsa bagi program Sarjana mengambil tempoh masa yang lama untuk menamatkan pengajian berbanding mahasiswa tempatan akibat daripada kesukaran dalam menyiapkan tugasan penyelidikan dan tekanan dalam menamatkan pengajian. Namun, mahasiswa antarabangsa bagi program Doktor Falsafah mengambil tempoh masa yang lebih pendek untuk menamatkan pengajian kerana mereka telah disediakan kemudahan yang mencukupi dari segi kemudahan kewangan dan diberi peluang untuk bekerja di negara mereka melanjutkan pengajian. Jiranek (2010) dalam kajiannya mendapati mahasiswa antarabangsa di Fakulti Sains di Universiti Adelaide, Australia mengambil purata masa selama 4.3 tahun untuk menamatkan pengajian berbanding mahasiswa tempatan yang mengambil purata masa selama 5.1 tahun untuk menamatkan pengajian pasca ijazah mereka. Oleh itu, hipotesis 4 bagi kajian ini adalah:

Hipotesis 4: Terdapat perbezaan tempoh menamatkan pengajian dalam kalangan mahasiswa pasca ijazah mengikut status kewarganegaraan.

Seagram (1998) mendapati program pengajian adalah signifikan dengan tempoh masa mahasiswa menamatkan pengajian.Mahasiswa yang mengikuti program pengajian Geografi lebih cepat menamatkan pengajian berbanding mahasiswa yang mengikuti program pengajian Kemasyarakatan dan Sains Sosial. Namun, Sheridan dan Pyke (1994) menunjukkan mahasiswa Sarjana yang mengambil program pengajian Kemasyarakatan lambat menamatkan pengajian berbanding program pengajian lain. Mahasiswa Doktor Falsafah yang mengikuti program pengajian Geografi lebih lambat menambatkan pengajian daripada program pengajian lain. Memandangkan kajian lalu menunjukkan terdapat perbezaan tempoh tamat pengajian berdasarkan bidang-bidang tertentu, maka, hipotesis 5 bagi kajian ini adalah:
Hipotesis 5: Terdapat perbezaan tempoh menamatkan pengajian dalam kalangan mahasiswa pasca ijazah mengikut program pengajian.

Kajian daripada Kam (1997), Norhasni dan West (2007), Norhasni (2006), Phillips dan Pugh (2005), Binns (2006), dan Donald (1995) menekankan aspek tanggungjawab mahasiswa terhadap kerja-kerja penyelidikan yang mempunyai 13 senarai tugas meliputi pemilihan topik kajian, perancangan kerja, penentuan skop penyelidikan, pencarian kajian lepas, persediaan proposal penyelidikan, penubuhan metodologi penyelidikan, pemantauan kerja penyelidikan, mengambil berat akan kemajuan penyelidikan, memastikan kualiti kerja dan standard mengikut piawaian yang ditetapkan, menghantar draft penyelidikan bagi tujuan semakan, memperoleh kemahiran penulisan tesis, menjangkakan masalah dan berinteraksi antara mahasiswa. Donald (1995) juga menyatakan tanggungjawab mahasiswa untuk menghadirkan diri dalam kursus-kursus latihan yang dikehendaki oleh fakulti dan disyorkan oleh penyelia.Malah, mahasiswa juga bertanggungjawab untuk mengekalkan hubungan yang baik dengan penyelia dan mewujudkan komunikasi dua hala yang berkesan.Mahasiswa turut bertanggungjawab dalam mematuhi tarikh akhir untuk penghantaran tesis, menyediakan pelan penyelidikan, mewujudkan jawatankuasa penyelidikan, memaklumkan kepada penyelia berhubung sebarang perubahan ke atas penyelidikan, dan mengekalkan rekod yang baik agar penyelidikan dapat diselesaikan dengan sempurna (Binns, 2006). Dapatan kajian lepas jelas menunjukkan kebertanggungjawaban mahasiswa terhadap pengajiannya akan mempengaruhi tempoh tamat pengajiannya. Maka, hipotesis 6 bagi kajian ini adalah:

Hipotesis 6: Rasa kebertanggungjawaban mahasiswa terhadap pengajiannya akan mempengaruhi tempoh tamat pengajian.

Bagi Binns (2006), Norhasni (2006), dan Norhasni et al., (2009) penyelia juga memainkan tanggungjawab penting terhadap tempoh masa mahasiswa menamatkan pengajian. Penyeliaan yang terbaik adalah penyelia yang memberi bimbingan dalam pemilihan dan perancangan topik kajian, menggalakkan keadaan yang kondusif dan perkembangan intelektual mahasiswa, mewujudkan jadual kerja mengikut fasa, memberikan maklum balas kepada kerja penyelidikan mahasiswa, memastikan mahasiswa memahami teori, metodologi dan kemahiran teknikal, memberi nasihat dan menggalakkan mahasiswa menghadirkan diri dan mempersembahkan kajian di persidangan, menggalakkan untuk menerbitkan hasil penyelidikan dalam jurnal, menjaga hubungan yang baik dengan mahasiswa seliaan, dan memberi sokongan peribadi kepada mahasiswa. Norhasni (2006) dan Norhasni et al., (2009) menyatakan penyelia bertanggungjawab untuk mempunyai pengetahuan, kepakaran dan pengalaman dalam bidang penyelidikan yang diselia. Oleh itu, hipotesis 7 bagi kajian ini adalah:

Hipotesis 7: Kebertanggungjawaban dan komitmen penyelia akan mempengaruhi tempoh tamat pengajian mahasiswa pasca ijazah.

Menurut Norhasni dan West (2007), komunikasi interpersonal dan hubungan baik antara mahasiswa dan penyelia penting dalam proses penyeliaan. Tanpa komunikasi terbuka dan jujur, kedua-dua pihak akan menghadapi kesukaran untuk mengenal pasti jenis dan sebab-sebab kekurangan yang dihadapi oleh mahasiswa. Komunikasi interpersonal ini penting dalam memastikan mahasiswa dapat melakukan kemajuan penyelidikan dengan konsisten dan berjaya mempersembahkan hasil penyelidikan atau disertasi tepat pada masa dan mengikut piawaian atau standard 
yang telah ditetapkan (Norhasni \& West, 2007; Norhasni, 2006).Perjumpaan secara efektif juga penting memandangkan mahasiswa dan penyelia mempunyai matlamat yang ingin dicapai.Selain itu, proses penyelidikan dapat dijalankan dengan lancar dan penyelia dapat memberi panduan dan nasihat kepada mahasiswa untuk menamatkan pengajian pada masa yang telah ditetapkan. Bagi Norhasni et al., (2009), kedua-dua pihak perlu memainkan peranan penting dalam mengekalkan komunikasi interpersonal atau hubungan sepanjang tempoh program pasca ijazah. Dapatan kajian menunjukkan bahawa mahasiswa tempatan berpuas hati dengan komunikasi antara penyelia dan mahasiswa antarabangsa pula lebih cenderung untuk kerap bertemu dengan penyelia mereka bagi membincangkan tentang penyelidikan mereka. Maka, hipotesis 8 kajian ini adalah:

\section{Hipotesis 8: Hubungan interpersonal antara mahasiswa dan penyelia mempengaruhi tempoh tamat pengajian.}

Kajian daripada Seagram (1998), Sheridan dan Pyke (1994) dan Jiranek (2010) mendapati sokongan kewangan yang meliputi biasiswa negeri, biasiswa universiti, pembiayaan bantuan mengajar, pembiayaan pembantu penyelidik, pinjaman mahasiswa dan bantuan kewangan daripada keluarga dan sebagainya sebagai mempengaruhi tempoh pengajian mahasiswa menamatkan pengajian. Seagram (1998) mendapati bahawa mahasiswa pasca ijazah yang menerima sokongan kewangan dalam bentuk pembiayaan bantuan mengajar dan pembiayaan pembantu penyelidik lambat untuk menamatkan pengajian. Kajian Sheridan dan Pyke (1994) pula menunjukkan mahasiswa pasca ijazah yang menerima sokongan kewangan berbentuk dana yang diterima daripada pelbagai sumber seperti biasiswa, geran dan pembiayaan bantuan mengajar dilihat mengambil tempoh masa yang lebih lama untuk menamatkan pengajian. Mahasiswa ijazah Doktor Falsafah yang menerima sokongan kewangan berbentuk geran dilihat mengambil tempoh masa yang lebih lama berbanding mahasiswa yang mendapat sokongan kewangan dalam bentuk bantuan pembiayaan mengajar yang lebih cepat menamatkan pengajian. Bagi Jiranek (2010), mahasiswa pasca ijazah di Fakulti Sains yang menerima biasiswa dilihat berjaya menamatkan pengajian lebih awal berbanding mahasiswa pasca ijazah yang tidak menerima biasiswa. Dapatan kajian lepas jelas menunjukkan tempoh masa pengajian dipengaruhi oleh bantuan kewangan yang diterima.Namun begitu, kesan pengaruhnya dilihat berbeza di mana ada yang dapat menamatkan pengajian awal dan ada yang lebih lama. Berkemungkinan projek penyelidikan yang menerima geran adalah lebih kompleks berbanding projek penyelidikan yang tidak menerima dana. Mungkin keadaan ini yang menyebabkan kelewatan tamat pengajian.Manakala, bagi penerima biasiswa pula, mereka dapat membuat penyelidikan tanpa terikat dengan kontrak geran malah tiada masalah kewangan yang runcing.Keadaan yang berbeza ini memberi kelebihan kepada penerima biasiswa berbanding mahasiswa yang menerima geran penyelidikan. Oleh itu, hipotesis 9 kajian ini adalah:

\section{Hipotesis 9: Sokongan kewangan mempengaruhi tempoh tamat pengajian.}

Norhasni (2006) menyatakan perkhidmatan sokongan fakulti mempengaruhi tempoh tamat pengajian terutama dalam kalangan mahasiswa antarabangsa.Mahasiswa antarabangsa dilihat lambat menamatkan pengajian kerana mereka tidak berpuas hati dengan perkhidmatan sokongan fakulti.Mahasiswa antarabangsa dilihat mempunyai masalah dalam menyesuaikan diri dengan persekitaran baru seperti kekangan bahasa, perbezaan budaya dan kurang penyeliaan daripada penyelia. Justeru, perkhidmatan sokongan akan membantu pelajar untuk cepat menyesuaikan diri dan seterusnya dapat belajar dengan lebih baik. Kajian daripada Ryan (2003) membuktikan bahawa perkhidmatan sokongan fakulti dari segi kewangan dan akademik mempunyai kesan positif dan signifikan dengan tempoh tamat pengajian mahasiswa.Hoskins dan Goldberg (2005) dan Creighton (2007) pula memfokuskan kepada hubungan antara mahasiswa dan fakulti sebagai faktor yang mempengaruhi tempoh tamat pengajian mahasiswa. Oleh itu, Berdasarkan senario di atas, maka hipotesis 10 kajian ini adalah:

\section{Hipotesis 10: Perkhidmatan sokongan fakulti mempengaruhi tempoh tamat pengajian.}

\subsection{Perkongsian Pengetahuan Sebagai Moderator}

Takrif perkongsian pengetahuan boleh diringkaskan sebagai satu proses mendapatkan pengetahuan seseorang dan kepakaran organisasi, lalu disebarkan kepada orang lain dalam organisasi yang boleh membantu menghasilkan pulangan yang besar kepada individu dan organisasi (Krogh, 2000). Lee (2001) mendefinisikan perkongsian pengetahuan sebagai suatu aktiviti yang melibatkan pertukaran pengetahuan sama ada berbentuk tersurat atau tersirat dalam kalangan individu, kumpulan atau organisasi lain. Aktiviti perkongsian penting kepada individu atau mahasiswa dalam memperoleh pencapaian yang terbaik dalam prestasi mahasiswa. Ini kerana, melalui aktiviti perkongsian pengetahuan, individu atau mahasiswa akan dapat memperoleh pengetahuan baru, meningkatkan kefahaman terhadap sesuatu perkara baru dan seterusnya dapat menyelesaikan permasalahan yang wujud dalam pembelajaran (Yuen \& Majid, 2007; Hogberg \& Edvission, 1998). Hal ini secara langsung akan memudahkan proses penyelidikan dijalankan dengan lancar dan mahasiswa dapat menamatkan pengajian dengan lebih cepat daripada jangkaan.

Faktor individu dari segi sikap atau tingkah laku mahasiswa seperti gemar berkongsi pendapat dan idea dari mereka yang lebih pakar seperti penyelia dan rakan-rakan (Wright \& Cochrane, 2000). Sikap dan tingkah laku yang ditunjukkan ini akan memberi kesan positif dari segi jangkaan tempoh tamat pengajian yang dapat dipercepatkan di mana segala permasalahan yang wujud dalam penyelidikan dapat diselesaikan dengan segera. Selain itu, faktor individu mahasiswa dari segi tindak balas mahasiswa terhadap aktiviti perkongsian pengetahuan juga mempengaruhi jangkaan tempoh tamat pengajian (Hussein \& Nassuora, 2011). Mahasiswa memberikan tindak balas positif terhadap aktiviti perkongsian pengetahuan seperti sentiasa berkongsi pengetahuan dengan mahasiswa lain.

Sekiranya individu atau mahasiswa mempunyai tahap perkongsian pengetahuan yang tinggi, maka, jangkaan tempoh tamat pengajianakan dapat dipercepatkan. Oleh itu, hipotesis 11 kajian ini adalah:

\section{Hipotesis 11: Hubungan yang positif antara faktor individu dengan jangkaan tempoh tamat pengajian adalah lebih kuat bagi mahasiswa pasca ijazah yang mempunyai tahap perkongsian pengetahuan yang tinggi berbanding mahasiswa pasca ijazah yang mempunyai tahap perkongsian pengetahuan yang rendah.}

Kajian Lubega dan Niyitegeka (2008) pula mendapati kualiti seliaan dengan menggunakan aplikasi teknologi yang dikenali sebagai e-penyeliaan telah digunakan dalam pembelajaran di peringkat pendidikan tinggi. Era teknologi pada masa kini dan modul-modul yang menggunakan teknologi telah memudahkan mahasiswa pasca ijazah untuk melalui proses e-penyeliaan. Penyelia dan mahasiswa seliaan boleh mempelajari bagaimana untuk saling menghormati, menghargai dan berkongsi pengetahuan antara satu sama lain sebagai tanda komitmen kepada proses 
penyeliaan (Lubega \& Niyitegeka, 2008). Kajian ini telah menunjukkan keberkesanan proses e-penyeliaan dan memberi kesan positif kepada prestasi penyelidikan mahasiswa pasca ijazah. Sekiranya penyelia dan mahasiswa mempunyai tahap perkongsian pengetahuan yang tinggi, maka, kualiti penyeliaan akan berjalan dengan lancar berbanding penyelia dan mahasiswa yang mempunyai tahap perkongsian pengetahuan yang rendah.Hal ini secara langsung melancarkan proses penyeliaan antara penyelia dan mahasiswa seliaan dan mahasiswa dapat menamatkan pengajian dengan lebih cepat daripada jangkaan.

Selain itu, Lange et al., (2011) menyatakan bahawa kualiti seliaan adalah terdiri daripada penyelia, kakitangan akademik dan kumpulan mahasiswa pasca ijazah. Perkongsian pengetahuan yang terjalin antara mahasiswa dengan penyelia, kakitangan akademik dan kumpulan mahasiswa pasca ijazah dalam aktiviti perkongsian pengetahuan berkemungkinan dapat menamatkan pengajian dengan lebih cepat. Ia berkemungkinan bahawa aktiviti perkongsian pengetahuan juga menyumbang kepada penglibatan aktiviti perkongsian pengetahuan sebagai pemangkin antara hubungan faktor kualiti seliaan dengan jangkaan tempoh tamat pengajian. Oleh itu, hipotesis 12 kajian ini adalah:

Hipotesis 12: Hubungan yang positif antara kualiti seliaan dengan jangkaan tempoh tamat pengajian adalah lebih kuat bagi mahasiswa pasca ijazah yang mempunyai tahap perkongsian pengetahuan yang tinggi berbanding mahasiswa pasca ijazah yang mempunyai tahap perkongsian pengetahuan yang rendah.

Kajian Soon dan Fraser (2011) telah meneroka pengetahuan yang boleh ditukar dan dikongsi bersama dalam kalangan mahasiswa pasca ijazah yang mengikuti pengajian secara jarak jauh dalam aktiviti kerja kumpulan atas talian atau dengan menggunakan alat teknologi melalui aplikasi internet sebagai medium bagi aktiviti perkongsian pengetahuan.Kajian ini telah menyelidiki aktiviti perkongsian pengetahuan dalam kalangan mahasiswa pasca ijazah yang dikenali sebagai "Maklumat Pengurusan Organisasi" di mana aktiviti ini meneroka sistem pengurusan pembelajaran atau learning management system (LMS).Mahasiswa telah menggunakan aplikasi Wikis dalam menyerahkan tugasan bagi projek yang dijalankan.Kajian mendapati bahawa dengan menggunakan alat teknologi dalam internet, pelbagai ciri interaksi dapat digunakan dalam aktiviti perkongsian pengetahuan, sebagai contoh, forum, ruang sembang, wikis dan e-mel. Oleh itu kajian ini telah menunjukkan bahawa dengan menggunakan alat-alat teknologi secara efektif, maka mahasiswa pasca ijazah dapat bekerjasama dengan baik dalam melaksanakan tugas mengikut bidang kepakaran walaupun berada pada perbezaan zon masa (Soon \& Fraser, 2011).

Pengaruh aktiviti perkongsian pengetahuan ini dilihat membantu mahasiswa pasca ijazah melaksanakan tugasan dengan lebih efektif dan efisien dan meningkatkan sistem pengurusan pembelajaran mahasiswa pasca ijazah. Hal ini secara langsung mempercepatkan aktiviti penyelidikan yang dijalankan menerusi sokongan organisasi dan mahasiswa dapat menamatkan pengajian dengan lebih cepat daripada jangkaan.Sekiranya mahasiswa mempunyai tahap perkongsian pengetahuan yang tinggi, maka, aktiviti penyelidikan dapat dijalankan dengan lebih efektif dan efisien berbanding mahasiswa yang mempunyai tahap perkongsian pengetahuan yang rendah. Ia berkemungkinan bahawa aktiviti perkongsian pengetahuan juga menyumbang kepada penglibatan aktiviti perkongsian pengetahuan sebagai pemangkin antara hubungan faktor sokongan organisasi dengan jangkaan tempoh tamat pengajian. Hipotesis 13 bagi kajian ini adalah:

Hipotesis 13: Hubungan yang positif antara sokongan organisasi dengan jangkaan tempoh tamat pengajian adalah lebih kuat bagi mahasiswa pasca ijazah yang mempunyai tahap perkongsian pengetahuan yang tinggi berbanding mahasiswa pasca ijazah yang mempunyai tahap perkongsian pengetahuan yang rendah.

\subsection{METODOLOGI KAJIAN}

Populasi kajian ini melibatkan mahasiswa pasca ijazah penyelidikan di Fakulti Pendidikan (FP) dan Fakulti Pengurusan dan Pembangunan Sumber Manusia (FPPSM), Universiti Teknologi Malaysia (UTM) seramai 750 orang.Jadual Penentuan Saiz Sampel oleh Krejcie dan Morgan (1970) menyatakan sekiranya bilangan populasi kajian adalah seramai 750 orang, maka saiz sampel yang diperlukan adalah seramai 254 orang responden. Dalam kajian ini, teknik persampelan sistematik telah digunakan. Instrument kajian yang digunakan adalah satu set soal selidik Evaluation of Postgraduate Supervision (SEPS) yang diadaptasi daripada Queenland University of Technology (QUT), (1995). Borang soal selidik ini telah diedarkan kepada responden melalui dalam talian (online survey) di mana, kajian menggunakan alamat emel mahasiswa pasca ijazah di bidang Sains Sosial, UTM, Johor Bahru yang diperoleh daripada SPS, UTM. Aplikasi perisian "Google Docstoc" digunakan untuk memuat naik borang soal selidik dan responden menjawab soal selidik dengan menggunakan aplikasi perisian tersebut.Skala Rating Likert yang menggunakan angka 1,2,3, 4, dan 5 untuk mewakili tahap persetujuan responden terhadap sesuatu pernyataan. Soal selidik ini dibahagikan kepada tiga bahagian iaitu bahagian A, B dan C. Bahagian A merupakan latar belakang responden yang meliputi jantina, umur, bangsa, status, fakulti, tahap pengajian, jenis pengajian, tempoh pengajian, bentuk pendaftaran dan sokongan kewangan. Dalam meneliti faktor-faktor penentu kejayaan mahasiswa menamatkan pengajian, instrumen Evaluation of Postgraduate Supervision (SEPS) yang diadaptasi daripada Queenland University of Technology (QUT), (1995). Bahagian ini mengandungi 64 item soalan.Ketiga-tiga faktor tersebut telah dibahagikan kepada faktor-faktor kecil. Faktor-faktor tersebut diterima pakai berasaskan daripada sorotan kajian. Walau bagaimanapun, item soalan tersebut telah diubah suai bersesuaian dengan kajian yang ingin dijalankan dan telah diuji kebolehpercayaan dan kesahihan. Bagi intensiti aktiviti perkongsian pengetahuan, instrumen yang telah dibina oleh Ting dan Mohd Shaheen (2006) diubah suai mengikut kajian. Bahagian ini mengandungi 11 item soalan yang terdiri daripada 2 bahagian iaitu amalan dalam aktiviti perkongsian pengetahuan dan aktivitiaktiviti perkongsian pengetahuan. Kebolehpercayaan item ditentukan melalui pekali nilai Alfa-Cronbach. Nilai keseluruhan alfa ialah .82 iaitu nilai yang diterima serta melebihi nilai .70, iaitu nilai minimum untuk kajian berbentuk tinjauan seperti Jadual 1. 
Jadual 1 Ujian kebolehpercayaan

\begin{tabular}{lcc}
\hline & Pemboleh ubah-pemboleh ubah & Cronbach Alfa \\
\hline Faktor individu & 0.820 \\
Faktor Kualiti Seliaan & & 0.939 \\
Faktor Sokongan Organisasi & & 0.903 \\
Intensiti Aktiviti Perkongsian Pengetahuan & 0.870 \\
& Keseluruhan Kebolehpercayaan & 0.818 \\
\hline
\end{tabular}

Model kajian ini adalah seperti berikut.

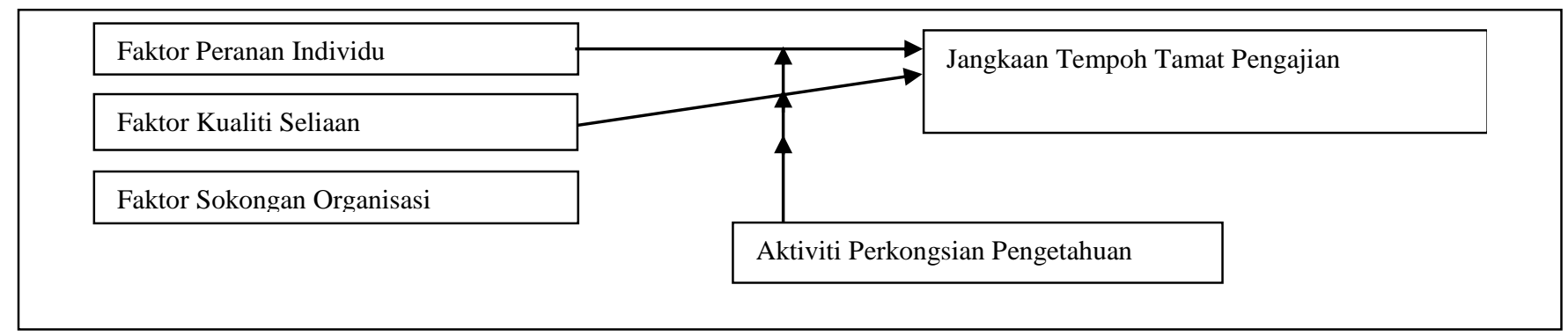

Rajah 1 Model kajian

\subsection{HASIL KAJIAN}

Analisis kajian menggunakan perisian komputer Statistical Package for Social Sciences (SPSS) versi 18.0. Seramai 210 orang mahasiswa pasca ijazah penyelidikan yang terlibat dalam kajian berbanding seramai 254 orang responden yang dijadikan sampel kajian. Analisis statistik deskriptif digunakan bagi melihat jumlah bilangan dan peratusan responden bagi latar belakang responden. Analisis ujian-t digunakan dalam melihat perbezaan jangkaan tempoh tamat pengajian berdasarkan faktor demografi mahasiswa pasca ijazah penyelidikan. Analisis regresi berganda pula digunakan dalam melihat hubungan antara faktor individu, faktor kualiti seliaan dan faktor sokongan organisasi dengan jangkaan tempoh tamat pengajian. Analisis regresi berganda berhirarki digunakan bagi melihat aktiviti perkongsian pengetahuan sebagai moderator bagi perhubungan antara faktor individu, faktor kualiti seliaan dan faktor sokongan organisasi dengan jangkaan tempoh tamat pengajian.

\subsection{Perbezaan Jangkaan Tempoh Tamat Pengajian Berdasarkan Faktor Demografi}

Analisis ujian-t bagi hasil kajian perbezaan jangkaan tempoh tamat pengajian mengikut jantina mahasiswa adalah signifikan dengan nilai min 0.0001 . Aras signifikan yang ditetapkan adalah 0.005. Oleh itu, hasil menunjukkan terdapat perbezaan antara jangkaan tempoh tamat pengajian mengikut jantina. Status perkahwinan mahasiswa juga adalah signifikan pada aras 0.000 . Ini menunjukkan terdapat perbezaan antara jangkaan tempoh tamat pengajian mengikut status perkahwinan mahasiswa. Bagi status pendaftaran mahasiswa, didapati aras signifikan adalah sebanyak 0.000 . Oleh itu, status pendaftaran mahasiswa juga adalah signifikan di mana terdapat perbezaan jangkaan tempoh tamat pengajian mengikut status pendaftaran. Hasil kajian bagi status kewarganegaraan mahasiswa adalah signifikan dengan aras signifikan sebanyak 0.048 dan menunjukkan terdapat perbezaan jangkaan tempoh tamat pengajian mengikut status kewarganegaraan. Program pengajian mahasiswa adalah tidak signifikan pada aras 0.196 dan ini menunjukkan tidak terdapat perbezaan jangkaan tempoh tamat pengajian mengikut program pengajian mahasiswa. Jadual 2 menunjukkan rumusan bagi hasil kajian perbezaan jangkaan tempoh tamat pengajian berdasarkan faktor demografi.

4.2 Hubungan Antara Faktor Individu, Faktor Kualiti Seliaan dan Faktor Sokongan Organisasi dengan Jangkaan Tempoh Tamat Pengajian.

Jadual 3 menunjukkan hasil bagi hubungan antara faktor individu, faktor kualiti seliaan dan faktor skongan organisasi dengan jangkaan tempoh tamat pengajian. Model regresi menunjukkan bahawa 10.1 peratus perubahan dalam jangkaan tempoh tamat pengajian disebabkan oleh hubungan dengan faktor individu, faktor kualiti seliaan dan faktor sokongan organisasi. Hasil juga menunjukkan faktor individu, faktor kualiti seliaan dan faktor sokongan organisasi mempunyai hubungan yang signifikan dengan jangkaan tempoh tamat pengajian. 
Jadual 2 Perbezaan jangkaan tempoh tamat pengajian mengikut faktor demografi

\begin{tabular}{|c|c|c|c|c|}
\hline Faktor Demografi & Min & Sisihan Piawai & Nilai t & Nilai p \\
\hline \multicolumn{5}{|l|}{ Jantina $(\mathrm{n}=\mathbf{2 1 0})$} \\
\hline Lelaki $(\mathrm{n}=101)$ & 8.1782 & 2.37232 & -3.534 & 0.001 \\
\hline Perempuan $(n=109)$ & 9.2569 & 2.02028 & & \\
\hline \multicolumn{5}{|l|}{ Status Perkahwinan $(n=210)$} \\
\hline Bujang $(\mathrm{n}=54)$ & 6.8148 & 1.98175 & -8.384 & 0.000 \\
\hline Berkahwin $(n=156)$ & 9.4038 & 1.94697 & & \\
\hline \multicolumn{5}{|l|}{ Status Pendaftaran $(\mathrm{n}=\mathbf{2 1 0})$} \\
\hline Sepenuh masa $(\mathrm{n}=127)$ & 127.3622 & 13.79523 & 16.674 & 0.000 \\
\hline Separuh masa $(n=83)$ & 193.5743 & 34.41648 & & \\
\hline \multicolumn{5}{|l|}{ Status kewarganegaraan $(n=210)$} \\
\hline Mahasiswa tempatan $(\mathrm{n}=153)$ & 9.1053 & 1.74933 & -1.665 & 0.048 \\
\hline Mahasiswa antarabangsa $(\mathrm{n}=57)$ & 8.6013 & 2.40979 & & \\
\hline \multicolumn{5}{|l|}{ Program Pengajian $(n=210)$} \\
\hline Pengurusan dan Pembangunan Sumber Manusia $(n=104)$ & 8.1154 & 1.73657 & 1.298 & 0.196 \\
\hline Pendidikan $(\mathrm{n}=106)$ & 7.7736 & 2.06690 & & \\
\hline
\end{tabular}

Jadual 3 Hubungan antara faktor individu, faktor kualiti seliaan dan faktor sokongan organisasi dengan jangkaan tempoh tamat pengajian

\begin{tabular}{lrrr}
\hline \multicolumn{1}{c}{ Pemboleh ubah } & Beta & t & Sig. \\
\hline Jangkaan tempoh tamat pengajian & & .000 \\
Skorindividu & -.131 & 5.187 & -1.820 \\
Skorkualitiseliaan & -.042 & -.487 & .030 \\
Skorsokonganorganisasi & .355 & .027 \\
R=0.318, $\mathrm{R}^{2}=0.101$ & & 4.239 \\
\hline
\end{tabular}

4.3 Aktiviti Perkongsian Pengetahuan Merupakan Moderator Bagi Perhubungan Antara Faktor Individu, Faktor Kualiti Seliaan dan Faktor Sokongan Organisasi Dengan Jangkaan Tempoh Tamat Pengajian.

Hasil kajian telah membuktikan bahawa kesan interaksi antara aktiviti perkongsian pengetahuan dan faktor individu adalah tidak signifikan pada aras 0.256 daripada aras signifikan yang ditetapkan iaitu 0.05. Maka, aktiviti perkongsian pengetahuan dilihat sebagai bukan moderator bagi perhubungan antara faktor individu dengan jangkaan tempoh tamat pengajian. Namun, hasil kajian telah membuktikan bahawa kesan interaksi antara aktiviti perkongsian pengetahuan dan faktor kualiti seliaan dan faktor sokongan organisasi adalah signifikan pada aras 0.046 dan 0.047 daripada aras signifikan yang ditetapkan iaitu 0.05. Maka, aktiviti perkongsian pengetahuan merupakan moderator bagi perhubungan antara faktor kualiti seliaan dan faktor sokongan organisasi dengan jangkaan tempoh tamat pengajian. Dapatan kajian ditunjukkan dalam Jadual di bawah.

Jadual 4.1 Regresi berganda berhirarki bagi faktor individu dan aktiviti perkongsian pengetahuan

\begin{tabular}{|c|c|c|c|c|}
\hline \multirow[t]{3}{*}{ Pemboleh ubah } & \multicolumn{4}{|c|}{ Pemboleh ubah bersandar } \\
\hline & \multicolumn{4}{|c|}{ Aktiviti Perkongsian Pengetahuan $(\mathrm{N}=210)$} \\
\hline & L1 & L2 & L3 & L4 \\
\hline \multicolumn{5}{|l|}{ Pemboleh ubah kawalan } \\
\hline Jantina & 0.003 & 0.003 & 0.003 & 0.003 \\
\hline Umur & 0.906 & 0.902 & 0.818 & 0.835 \\
\hline Kaum & 0.401 & 0.403 & 0.443 & 0.416 \\
\hline Status & 0.637 & 0.655 & 0.637 & 0.647 \\
\hline Fakulti & 0.104 & 0.102 & 0.108 & 0.101 \\
\hline Tahap Pengajian & 0.000 & 0.000 & 0.000 & 0.000 \\
\hline Bentuk Pendaftaran & 0.000 & 0.000 & 0.000 & 0.000 \\
\hline Sokongan Kewangan & 0.810 & 0.892 & 0.804 & 0.796 \\
\hline \multicolumn{5}{|l|}{ Pemboleh ubah bebas } \\
\hline Faktor Individu & & 0.644 & 0.517 & 0.225 \\
\hline \multicolumn{5}{|l|}{ Moderator } \\
\hline Aktiviti Perkongsian Pengetahuan & & & 0.418 & 0.284 \\
\hline \multicolumn{5}{|l|}{ Interaksi Pemboleh ubah bebas dan Moderator } \\
\hline Faktor Individu X Aktiviti Perkongsian Pengetahuan & & & & 0.256 \\
\hline $\mathrm{F}$ & & 0.214 & 0.436 & 0.725 \\
\hline$\Delta \mathrm{F}$ & & 0.214 & 0.659 & 1.300 \\
\hline $\mathrm{R}^{2}$ & & 0.001 & 0.004 & 0.010 \\
\hline
\end{tabular}


Jadual 4.2 Regresi berganda berhirarki bagi faktor kualiti seliaan dan aktiviti perkongsian pengetahuan

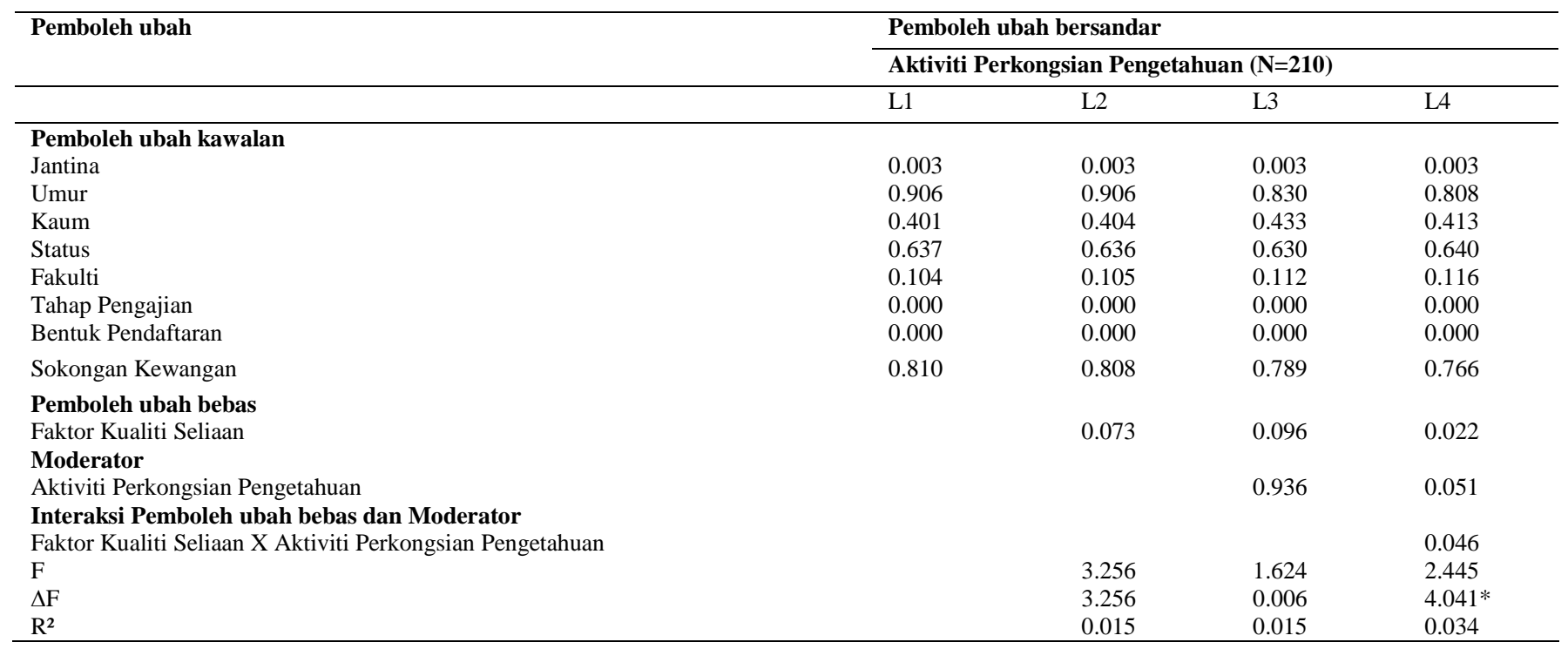

*korelasi adalah signifikan pada tahap 0.05

Jadual 4.3 Regresi berganda berhirarki bagi faktor sokongan organisasi dan aktiviti perkongsian pengetahuan

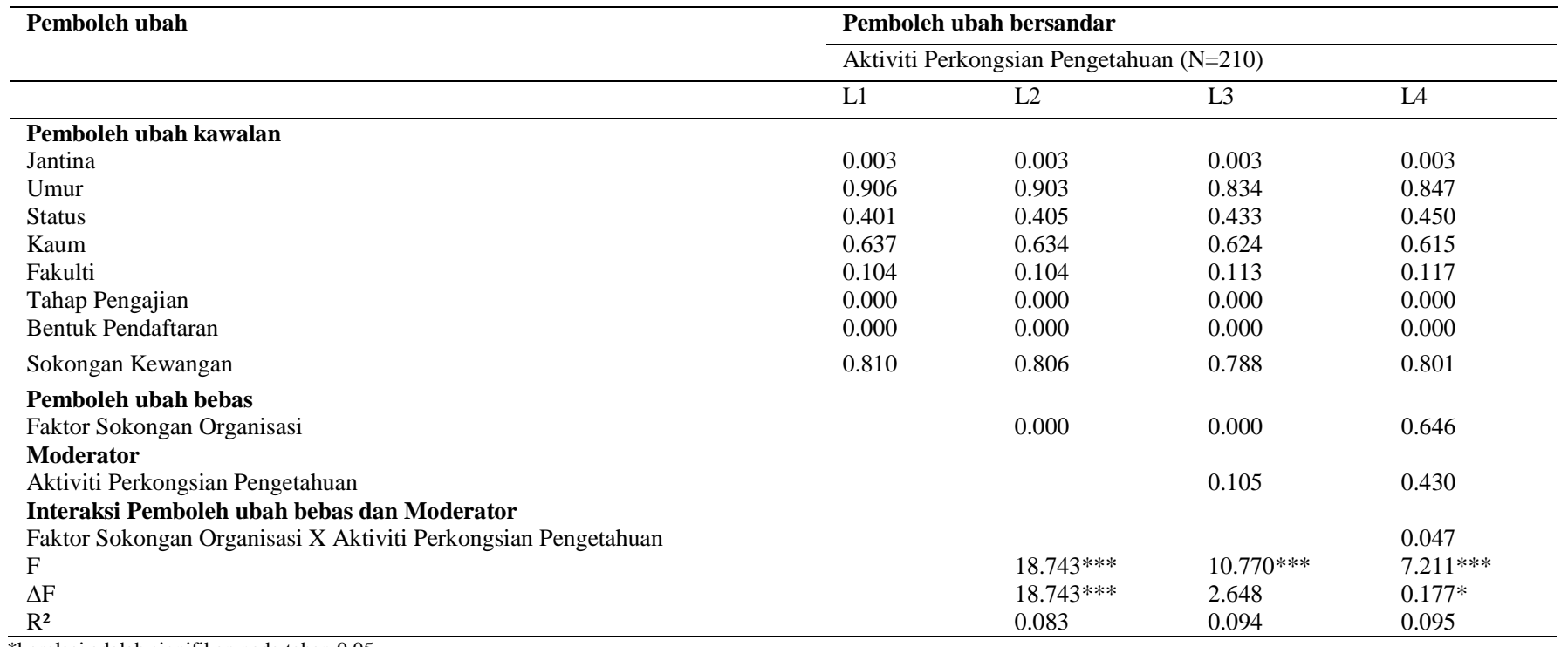

*korelasi adalah signifikan pada tahap 0.05

***korelasi adalah signifikan pada tahap 0.001 .

\subsection{PERBINCANGAN}

Perbezaan jangkaan tempoh tamat pengajian berdasarkan jantina mahasiswa mendapati bahawa mahasiswa lelaki menjangkakan bahawa mereka akan menamatkan pengajian dengan lebih cepat berbanding mahasiswa wanita. Hasil kajian ini dilihat selari dengan kajian yang telah dilakukan oleh Jiranek (2010), Tuckman et al., (1990) dan Yeates (1991) yang menyatakan bahawa mahasiswa lelaki dijangka lebih awal menamatkan pengajian kerana mahasiswa lelaki lebih bertanggungjawab terhadap aktiviti penyelidikan yang dilakukan. Mahasiswa lelaki juga dilihat lebih berinteraksi dengan penyelia berbanding mahasiswa wanita dan mahasiswa lelaki lebih peka terhadap aktiviti persekitaran yang berlaku sepanjang penyelidikan dilakukan. Bagi status perkahwinan, mahasiswa yang masih bujang menjangkakan akan menamatkan pengajian dengan lebih cepat berbanding mahasiswa yang sudah berkahwin. Kajian yang dilakukan oleh Stock dan Siegfried (2006) menyatakan bahawa mahasiswa bujang lebih berupaya mendapatkan kemudahankemudahan yang diperlukan dalam menyiapkan penyelidikan. Mahasiswa bujang juga lebih melibatkan diri dalam perbincangan konstruktif dengan penyelia untuk mengetahui kemajuan penyelidikan dan dilihat lebih mengikut garis panduan yang telah digariskan oleh institusi pendidikan masing-masing. Hasil bagi perbezaan jangkaan tempoh tamat pengajian mengikut status pendaftaran pula menunjukkan bahawa jumlah jangkaan tempoh tamat pengajian berdasarkan tempoh minimum bagi mahasiswa yang mendaftar secara sepenuh masa adalah sebanyak 127.36 peratus berbanding jumlah jangkaan tempoh tamat pengajian berdasarkan tempoh minimum bagi mahasiswa yang mendaftar 
secara separuh masa sebanyak 193.57 peratus. Menurut Sheridan dan Pyke (1994), mahasiswa yang mendaftar pengajian secara separuh masa lambat menamatkan pengajian disebabkan oleh kesukaran yang dihadapi seperti kesukaran dalam membahagikan masa dan komitmen antara tugas sebagai seorang mahasiswa dan tugas sebagai seorang pekerja. Manakala, perbezaan jangkaan tempoh tamat pengajian mengikut status kewarganegaraan pula menunjukkan bahawa mahasiswa antarabangsa menjangkakan akan menamatkan pengajian dengan lebih cepat berbanding mahasiswa tempatan. Menurut Wright dan Cochrane (2008), mahasiswa antarabangsa menjangkakan lebih cepat menamatkan pengajian disebabkan oleh kemasukan mahasiswa antarabangsa ke program-program yang berkaitan bagi sesebuah universiti adalah lebih kompetitif berbanding mahasiswa tempatan.Selain itu, sekatan visa yang dikenakan terhadap mahasiswa antarabangsa untuk tinggal lebih lama di negara tempat mereka belajar melalui pas pelajar memaksa mahasiswa pasca ijazah untuk menamatkan pengajian dalam tempoh masa yang telah ditetapkan oleh pihak universiti.

Bagi hubungan antara faktor individu dan jangkaan tempoh tamat pengajian menunjukkan hubungan yang signifikan di mana faktor individu ini melihat kepada kebertanggungjawaban mahasiswa pasca ijazah dalam mengendalikan pengajian mereka khususnya berkaitan dengan penyelidikan yang dijalankan. Kam (1997) menyatakan bahawa sifat tanggungjawab yang ada pada diri mahasiswa dan sifat tidak suka bergantung menjangkakan mereka akan menamatkan pengajian dalam tempoh masa yang lebih cepat. Mahasiswa pasca ijazah penyelidikan harus memberi komitmen yang tinggi terhadap penyelidikan yang dilakukan yang membolehkan penyelidikan dapat disiapkan dalam jangka masa yang ditetapkan. Malah Phillips dan Pugh (2005) juga ada menyatakan bahawa pengajian mahasiswa adalah tanggungjawab mahasiswa itu sendiri.Ini bermakna, mahasiswa pasca ijazah penyelidikan adalah sangat bertanggungjawab kepada pengajian mereka khususnya penyelidikan yang dilakukan.

Faktor kualiti seliaan dan jangkaan tempoh tamat pengajian juga menunjukkan hubungan yang signifikan dan melihat kepada kebertanggungjawaban penyelia dan komunikasi interpersonal antara penyelia dan mahasiswa pasca ijazah. Kajian daripada Binns (2006) mengkaji tentang kebertanggungjawaban penyelia dalam memimpin aktiviti penyelidikan mahasiswa seliaan mereka.Binns (2006) yang mengkaji tentang kebertanggungjawab penyelia dalam memimpin aktiviti penyelidikan mahasiswa seliaan menyatakan bahawa penyelia yang baik adalah penyelia yang menjalankan tanggungjawab yang baik kepada mahasiswa seliaan. Norhasni (2006) pula menyatakan bahawa penyelia bertanggungjawab dalam memastikan aktiviti penyelidikan mahasiswa berada pada landasan yang betul bagi mahasiswa untuk menamatkan pengajian pada masa yang telah ditetapkan. Malah, penyelia juga bertanggungjawab dalam melakukan seliaan mengikut kemampuan yang ada pada diri mahasiswa. Sokongan, bimbingan dan motivasi yang diberikan oleh penyelia kepada mahasiswa seliaan dilihat memberi perangsang kepada mahasiswa untuk menyiapkan aktiviti penyelidikan mereka. Selain itu, komunikasi interpersonal penting bagi kedua-dua belah pihak kerana komunikasi yang baik akan melancarkan perjalanan aktiviti penyelidikan yang dijalankan dan mahasiswa dapat menjangkakan tempoh tamat pengajian mereka. Komunikasi dua hala menerusi perjumpaan yang dilakukan antara kedua-dua belah pihak dilihat menjadi tunjang kepada kejayaan sesebuah penyelidikan. Perjumpaan secara efektif membantu melancarkan proses aktiviti penyelidikan yang dilakukan (Norhasni \& West, 2007). Norhasni et al., (2009) pula menyatakan bahawa hubungan dan komunikasi interpersonal yang baik perlu dikekalkan sepanjang tempoh berlangsungnya proses penyeliaan antara penyelia dan mahasiswa seliaan.

Hubungan antara faktor sokongan organisasi dan jangkaan tempoh tamat pengajian juga adalah signifikan dan melihat kepada kebertanggungjawaban fakulti. Menurut Norhasni (2006), tanggungjawab fakulti dalam menyediakan kemudahankemudahan asas seperti makmal yang berteknologi tinggi dan perkhidmatan fotokopi dan kemudahan bilik belajar yang selesa kepada mahasiswa mempengaruhi tempoh graduasi mahasiswa. Selain itu, tanggungjawab mahasiswa dalam menjaga kebajikan mahasiswa dan memberikan sistem sokongan penyeliaan yang baik juga membantu mahasiswa menjangkakan tempoh tamat pengajian mahasiswa. Di samping itu, sokongan kewangan yang diterima oleh mahasiswa pasca ijazah juga membantu mahasiswa menjangkakan tempoh graduasi mahasiswa.

Aktiviti perkongsian pengetahuan merupakan moderator bagi faktor kualiti seliaan dan faktor sokongan organisasi. Hasil kajian menunjukkan bahawa interaksi yang kuat wujud antara aktiviti perkongsian pengetahuan dengan faktor kualiti seliaan pada aras signifikan 0.046 dan faktor sokongan organisasi pada aras signifikan 0.047. Tahap perkongsian pengetahuan yang tinggi yang ditunjukkan oleh mahasiswa telah mewujudkan hubungan yang positif antara faktor-faktor penentu kejayaan dengan jangkaan tempoh tamat pengajian menjadi lebih kuat. Menurut Lubega dan Niyitegeka (2008), aktiviti perkongsian pengetahuan yang dijalankan menerusi proses e-penyeliaan telah memberi banyak kelebihan kepada penyelia dan mahasiswa seliaan itu sendiri. Era teknologi masa kini telah memberi banyak kemudahan kepada mahasiswa seliaan dalam mempersembahan kemajuan penyelidikan kepada penyelia. Aktiviti perkongsian yang wujud dalam faktor kualiti seliaan adalah seperti forum, kumpulan e-penyelidikan dan e-mel. Menerusi kaedah ini, penyelia dapat melakukan aktiviti seliaan dan dapat memberikan komitmen terhadap tugas sebagai penyelia kepada mahasiswa seliaan. Mahasiswa pasca ijazah penyelidikan juga dapat mengambil peluang dalam melaksanakan aktiviti-aktiviti penyelidikan dengan lebih aktif dan produktif dan ini memberi keistimewaan kepada mahasiswa pasca ijazah penyelidikan untuk menjangkakan tempoh graduasi dengan lebih cepat.

Manakala, bagi Soon dan Fraser (2011), interaksi yang wujud dalam aktiviti perkongsian dan faktor sokongan organisasi dapat dilihat menerusi aplikasi internet yang digunakan oleh mahasiswa dalam berkongsi pengetahuan dengan mahasiswa lain. Aktiviti perkongsian pengetahuan dapat dijalankan melalui wikis, ruang sembang, e-mel dan forum. Mahasiswa pasca ijazah penyelidikan berkongsi pengetahuan mengikut bidang kepakaran yang dimiliki dan mewujudkan perkembangan pengetahuan walaupun berada pada perbezaan zon masa.Ini memberi manfaat kepada setiap mahasiswa pasca ijazah penyelidikan dalam menambahkan pengetahuan dan memberi peluang kepada mahasiswa pasca ijazah penyelidikan memperbaiki aktivitiaktiviti penyelidikan seterusnya mahasiswa pasca ijazah penyelidikan dapat menjangkakan tempoh graduasi dengan lebih cepat. Kolokium dan seminar yang dijalankan oleh pihak fakulti kepada mahasiswa pasca ijazah penyelidikan juga memberi manfaat kepada mahasiswa dalam berkongsi pengetahuan bagi kemajuan penyelidikan yang dijalankan seperti yang dipersetujui oleh Sheng-Hsiao Chiu (2010). Mahasiswa pasca ijazah dapat mengambil peluang daripada kolokium dan seminar tersebut untuk bertanya pendapat dan menambahkan pengetahuan bagi memperbaiki penyelidikan agar penyelidikan dapat disempurnakan dengan jayanya.

Namun, aktiviti perkongsian pengetahuan bukan merupakan moderator bagi faktor individu kerana aktiviti perkongsian pengetahuan wujud dalam satu pasukan atau kumpulan dalam meningkatkan prestasi kumpulan (Srivastava et al., 2006). Bagi 
Johnson dan Johnson (1988), mahasiswa akan lebih cemerlang dalam pembelajaran melalui interaksi secara berkumpulan berbanding secara individu.

\subsection{KESIMPULAN}

Selaras dengan objektif Malaysia yang ingin menyasarkan seramai 100000 orang penduduk yang berkelulusan $\mathrm{PhD}$ dan kelayakan setaraf perlu dipertingkatkan dengan pelbagai usaha yang boleh dilakukan bagi menghasilkan lebih ramai modal insan yang berkaliber tinggi. Justeru, faktor-faktor penentu kejayaan yang mempengaruhi jangkaan tempoh tamat pengajian perlu diambil dengan lebih serius oleh mahasiswa pasca ijazah penyelidikan. Manakala, dunia masa kini yang sedang bergerak ke arah "pengetahuan yang berasaskan ekonomi" menjadikan pengetahuan sebagai faktor penting dalam ekonomi baru. Perkongsian pengetahuan yang tergolong dalam pengurusan pengetahuan boleh menjadi faktor pendorong kepada faktorfaktor penentu kejayaan untuk menjangkakan tempoh graduasi mahasiswa pasca ijazah.

\section{Rujukan}

Binns, A. 2006. Graduate Supervision: Guidelines for Students, Faculty and Administrators at the University of Pennsylvania. Office of the Provost: University of Pennyslvania.

Cude, W. 2001. The PhD Trap Revisited. Toronto: Dundurn Press.

Donald, J. G. 1995. Graduate Student Supervision Policies and Procedures: A Case Study of Issues and Factors Affecting Graduate Study. The Canadian Journal Higher Education. XXXV (3): 1-29.

Goh, S. C. 2002. Managing Effective Knowledge Transfer: An Integrative Framework and Some Practice Implications. Journal of Knowledge Management. 6(1): 23-30.

Gouldner, A. 1960.The Norm of Reciprocity. American Sociological Review. 25: $16-178$

Hogberg, C., dan Edvinsson, L. 1998. A Design for Futurising Knowledge Networking. Journal of Knowledge Management. 2(2): 81-92.

Jiranek, V. 2010. Potential Predictors of Timely Completion among Dissertation Research Students at an Australian Faculty of Sciences. International Journal of Doctoral Studies. 5: 1-13.

Johnson, D. W., dan Johnson, R. T. 1988. Cooperative learning: Two Heads Learn Better Than One. Retrieved May 10, 2012 from www.context.org/ICLIB/IC18/Johnson.htm.

Kam, B. H. 1997. Style and Quality in Research Supervision: The Supervisor Dependency Factor. Higher Education. 34(1): 81-103.

Krejcie, R. V., dan Morgan, D. W. 1970. Determining Sample Size for Research Activities. Educational and Psychological Measurement. 30: 608.

Leatherman, C. 2000. A New Push for ABD's to Cross the Finish Line. The Chronicle of Higher Education. 46(29): A18-19.

Lubega, J., dan Niyitegeka, M. 2008. Integrating E-Supervision in Higher Educational Learning. In Aisbett, J., Gibbon, G., Rodrigues, A. J., Kizza, M. J., Nath, R. and Renardel, G. R.: Strengthening the Role of ICT in Development. (4): 351-358.

Manathunga, C. 2002. Detecting and Dealing with Early Warning Signs in Postgraduate Research Education: A Work-In-Progress. In M. Kiley., \& G. Mullins (Eds.). Quality in Postgraduate Research: Integrating
Perspectives Conference Proceedings, Adelaide, April 18-19. Adelaide, Australia: Advisory Centre for University Education, The University of Adelaide. 80-88.

Magnuson, S., Wilcoxon, S. A., dan Norem, K. 2000. A Profile of Lousy Supervision: Experienced Counselors' Perspec-Tives. Counselor Education and Supervision. 39: 189-203.

Mitchell, H. 2005. Knowledge Sharing The Value of Storytelling International Journal of Organizational Behavior. 9(5): 632-641.

Mohd Sadiq, S., dan Salina, D. 2009. Knowledge Sharing in Higher Education Institutions Perspectives from Malaysia. J. Inform. Knowledge. Management System. 39: 125-142.

Norhasni, Z. A. 2006. Effective Practices in Graduating Student Supervision Using the Mentoring and Coaching Approaches. The Journal of Human Resource and Adult Learning. 159-165.

Norhasni, Z. A., Aminuddin, H., dan Abdul Razaq, A. 2009. Research Student Supervision: An Approach to Good Supervisory Practice. The Open Education Journal. 2: 11-16.

Norhasni, Z. A., dan West, M. 2007. Responsibilities of Graduate Student: The Review of Research Student Policies. Journal of Social Sciences. 3(1) 7-17.

Phillips, E. M., dan Pugh, D. S. 2005. How to Get a PhD- A Handbook For Students and Their Supervisors. New York: Open University Press.

Price, J. 2005. Marriage and Graduate Student Outcomes. Cornell Higher Education Research Institute (CHERI). 28: 1-18.

Queensland University of Technology Postgraduate Supervision Evaluation Project Team. 1995. Tracking Postgraduates Supervision. Brisbane: QUT.

Seagram, B. C., Gould, J., dan Pyke, S. W. 1998. An Investigation of Gender and Other Variables on Time to Completion of Doctoral Degrees. Research in Higher Education. 39: 319-335.

Sheridan, P. M., dan Pyke, S. W. 1994. Predictors of Time to Completion of Graduate Degrees. Canadian Journal of Higher Education. 24(2): 6888 .

Sheng-Hsiao Chiu. 2010. Students' Knowledge Sources and Knowledge Sharing in the Design Studio-an Exploratory Study. International Journal Technology Education. 20: 27-42.

Sizer, J. 2001. Research and the Knowledge Age. Tertiary Education and Management. 7(3): 227-30.

Smith, R. 2000. Done is Better than Perfect: The Current Crisis in US Higher Education, Its Multiple Consequences, and the Universities' Unwillingness to Fund a Possible Solution. IMP Magazine. 5-9.

Srivastava, A., Bartol, K. M., dan Locke, E. A. 2006. Empowering Leadership In Management Teams: Effects on Knowledge Sharing, Efficacy and Performance. Academy of Management Journal. 49(6): 1239-1251.

Soon, L., dan Fraser, C. 2011. Knowledge Sharing and Knowledge Exchange in Distance Education Online Group Work. International Journal of Information and Education Technology. 1(2): 156-162.

Stock, W. A., dan Siegfried, J.J. 2006. Time-to-degree for the Economics PhD. Class of 2001-2002. AEA Papers and Proceedings. 96(2): 467-474.

Ting, J. Y., dan Mohd Shaheen, M. 2007. Knowledge-sharing Patterns of Undergraduate Students in Singapore. Emerald Group Publishing Limited. 56(6): 485-494.

Tuckman, H., Coyle, S., dan Bae, Y. 1990. On Time to the Doctorate. Washington, DC: National Academy Press.

Wright, T., dan Cochrane, R. 2000. Factors Influencing Successful Submission of Ph.D Theses. Studies in Higher Education. 25(2): 181-195.

Yang, H. L., dan Wu, T. C. T. 2006. Knowledge Sharing in an OrganizationShare or not. International Conference on Computing \& Informatics. 17.

Yeats, M. 1991. Doctoral Graduation Rates in Ontario universities. Toronto, Ontario, Canada: Council of Ontario Universities Ontario Council on Graduate Studies. 